\title{
Met die oog op genesingsdienste in die Nederduitse Gereformeerde Kerk
}

J P J Theron

\author{
Abstract
}

Towards healing services in the Dutch Reformed Church

The position of the Dutch Reformed Church in South Africa with regard to the world wide recovery of the Church's healing ministry is discussed. Features of liturgical healing services of other denominational churches are utilised to develop a model for the Dutch Reformed Church in initiating this kind of public ministry.

\section{Nuwere ontwikkelinge in die kerklike diens van genesing}

Dit is algemeen bekend dat daar die afgelope paar dekades ' $n$ nuwe belangstelling in die kerklike diens van genesing ontwikkel het. Binne verskeie van die sogenaamde gevestigde kerke word hierdie saak in kommissies, werkgroepe en kerklike vergaderings aan die orde gestel. Dit het tot bepaalde vernuwende kerklike praktyke, genesingsdienste, genesingshuise en natuurlik ook tot voortgaande studie aanleiding gegee. 'n Goeie voorbeeld en weerspieëling van die verandering wat plaasgevind het, kan gevind word in die historiese en teologiese ontwikkelinge binne die Anglikaanse Kerk. Die Lambeth-Konferensies se uitsprake van 1958, 1968 en 1978, 'die meerdere implementering van hierdie praktyk asook die feit dat selfs biskoppe voltyds aangestel word om hierdie diens te bevorder, getuig ook hiervan. Vele ander kerke, groepe, institute en organisasies in die Verenigde Koninkryk en op die Europese Vasteland is deur middel van konferensies, adviseurs, publikasies en studiegroepe direk by die uitbouing van die kerklike diens van genesing betrokke ${ }^{3}$. In Amerika gebeur dieselfde byvoorbeeld binne die Lutherse ${ }^{4}$ Metodiste $^{5}$ en Presbiteriaanse kerke. In laasgenoemde geval het sinodale besluite die uitbouing van die diens van genesing op die vlak van die plaaslike gemeente aangemoedig ${ }^{6}$. Van besondere belang is dat dit juis 'n gereformeerdegemeente in Oklahoma City (Reformed Church in America) is - onder leiding van dr. Robert Wise - wie se genesingsbediening in vele kringe tans besondere respek afdwing ${ }^{7}$. Ook binne die Rooms-Katolieke Kerk het daar ná Vaticanum II ten opsigte van hierdie saak 'n merkwaardige verandering plaasgevind. Dit word onder andere deur M T Kelsey (Episkopaals) ${ }^{8}, \mathrm{~K} J$ Kraan (Gereformeerd) ${ }^{9}$ en $\mathrm{F}$ MacNutt (vroeër ' $n$ Rooms-Katolieke priester) ${ }^{10}$ genoem. Hulle bespreek die feit en die gevolge daarvan dat die Roomse sakrament genoem "die laaste oliesel", vanaf 1 Januarie 1974 verander is na die "salwing van siekes". Formeel beteken dit dat hierdie sakrament wat oorspronklik op Jakobus 5:14 e.v. gebou is en mettertyd omgebuig is om as salwing tot die dood te dien, nou weer as salwing tot genesing gesien word! ${ }^{11}$ Die ontdekking van die gawe van genesing in sy eie bediening en die implementering daarvan deur die vorige aartsbiskop van Lusaka, Zambië, is ' $n$ interessante verhaal in die verband. ${ }^{12}$ $\mathrm{H}$ Booth ${ }^{13}$ beskryf die ontwikkelende praktyk deur te sê: "Every week many hundreds 
of healing services are held in churches of almost every Christian denomination. This practice has developed as the natural consequence of a dramatic explosion of interest in the Churches' Ministry of Healing."

Hierdie aanduibare meerdere belangstelling vir die kerklike diens van genesing het $\mathrm{C}$ Peter Wagner van die School of World Missions (Fuller Theological Seminary) laat sê dat hy daarvan oortuig is dat teen die einde van hierdie eeu, elke gemeente (ten minste in die VSA) 'n gevestigde bediening van genesing sal hê. ${ }^{14}$

Bogenoemde gebeure en die situasie wat dit skep kan saamgevat word in die woorde van R Bayley: "From Pentecostals to Roman Catholics and in every major Protestant denomination, clergy and laity are exploring what it means to relate to Jesus Christ not only as Lord and Savior but also as Healer. What does this phenomenon imply for those who are committed to a historic position of 'always reforming'?"15

Die logiese vraag na die posisie van die Ned. Geref. Kerk ten opsigte van hierdie ontwikkelinge, moet beantwoord word. Meer toegespits: Sal daar ook mettertyd volgens die voorstel van Jac J Müller in 1975 - genesingsdienste binne die Ned. Geref. Kerk gehou kan word? ${ }^{16}$ Hierdie vraag word verder geïntensifiseer deur die feit dat daar ten opsigte van hierdie saak ook binne hierdie kerk verskuiwinge plaasvind waarmee rekening gehou sal moet word. Voorbeelde hiervan is die besluit van die Algemene Sinode van 1978 waarin die moontlike voorbestaan van die charismata - en dus ook die gawe van genesing - erken word ${ }^{17}$ asook uitsprake waarin daar met verwysing na die gawes van die Gees vir strukturele en liturgiese vernuwing gepleit word. ${ }^{18}$ Barnard sê selfs in die verband: "In die liturgie kom dit en moet dit steeds tot uitdrukking kom. Dus is dit 'n groot verarming en benadeling van die gemeente as hy die werk en gawes van die Gees in sy eredienste misken. ${ }^{19}$ Nog sterker gestel: Moet die kerk nie die aanverwante uitspraak van JAT Robinson ernstiger opneem nie? Hy sê: "There is no preaching of the Gospel consistent with the New Testament which does not include the charge 'Heal the sick'; without that it would simply be a different gospel. ${ }^{20}$ Die eintlike vraag is dus of ' $n$ meer doelgerigte diens van genesing nie binne die Ned. Geref. Kerk ontwikkel kan word nie. In hierdie artikel word die vraag egter toegespits op die liturgie: Sal die ontplooiing van ' $n$ liturgiese diens van genesing binne die kontoere van gereformeerde liturgiese beginsels ${ }^{21}$ kan inpas en sal dit ook in staat wees om fasette van die liturgie te verryk?

Uit 'n ander hoek beskou kan saam met Hollenweger gevra word: Sal die kerk nie sy boodskap veel beter - verbaal en nie-verbaal - kan kommunikeer - deur wel sodanige liturgiese dienste te inisieer nie? ${ }^{22}$

Om op hierdie vrae te kan antwoord sal dit goed wees om vooraf die karaktertrekke van die huidige genesingsbediening van die Ned. Geref. Kerk kortliks te beskrywe.

\section{Kenmerke van die huidige diens van genesing in die Ned. Geref. Kerk.}

\section{1 'n Omvattende benadering}

Uit die aard van die saak hang so 'n beskrywing saam met dit wat onder die begrip kerklike diens van genesing verstaan word. Wanneer hierdie begrip in die wydste sin moontlik gehanteer word, dui dit op kerklike diens aan mense in nood met die oog op die verligting en moontlike uitwissing van daardie nood. So verstaan, dit wil sê feitlik 
sinoniem met die begrippe diakonale diens of diens van barmhartigheid, is dit meteens moontlik om die volgende fasette te noem:

a) Elke erediens in die kerk kan as 'n genesingsdiens gesien word. Dit geld veral ten opsigte van die Nagmaalsdiens met die klem op belydenis, vergifnis en "die aanneem van die helende tekens van Jesus se bloed en liggaam". ${ }^{23}$

b) Dit het ' $n$ sterk amptelike karakter. Predikante, ouderlinge en diakens besoek elke week of op huisbesoek, of tydens siekebesoek of tydens ' $n$ informele besoek onberekenbaar baie mense wat in een of ander nood verkeer. Die positiewe resultaat van hierdie arbeid kan ook nie bepaal word nie. Talle getuienisse bestaan van mense wat hierdeur opgebou of selfs heeltemaal genees is. ${ }^{24}$ Hierdie versorgende en helende aspek van die kerk se werk is een van sy uitstaande kenmerke.

c) Dit is ' $n$ omvattende dienswerk. Die kerk se genesingsdiens word verder sigbaar in die predikantekorps wat spesiaal vir hospitaalbearbeiding en pastoraal-sielkundige dienste afgesonder word. Talle predikante het boonop besondere take om in verskillende tehuise (bv. tehuise vir dranksugtiges, ongehude moeders, ens.) te vervul.

' $n$ Vraag wat hier opduik is waarom hospitaalbearbeiding in die Transvaalse sinodes onder die kommissies vir Ampsbediening en Evangeliasie resorteer. Lê die klem op siek mense wat in die hospitaal gehelp moet word om weer hulle (geestelike-) godsdienstige verhoudinge te deurdink of lê dit by die gedagte dat dit amptelike kerklike werk is wat gedoen word? In die Kaapse sinodes word hierdie bearbeiding gesien as diens van barmhartigheid. Aangesien daar heel waarskynlik ' $n$ ingewikkelde historiese verloop van sake hieraan verbonde is, sal die agtergrond nie hier verder beredeneer word nie. Wat wel vermoed kan word is dat dit in beide gevalle nie primêr om die fisiese genesing van die persoon gaan nie. Weliswaar kan gesê word dat barmhartigheidsdiens wel met omvattende nood te doen het. Spesifiek in die hospitaal word hierdie faset egter vermoedelik totaal aan die mediese wetenskap oorgelaat. Buitendien word die predikante wat in hierdie poste aangestel word, gekeur op grond van hulle kundigheid ten opsigte van beraad en die siektesituasie, maar nie op grond van die vraag of die gawe van genesing van tyd tot tyd deur hulle bediening na vore kom nie. Op ' $n$ variante wyse is dieselfde ook waar van die werkers (amptelike - en lekewerkers) wat in die Transvaalse hospitale gebruik word. Hier staan "geestelike versorging" ook voorop.

d) Vroeër het die kerk veral in die sendingveld hospitale opgerig ('n lokaas of vangmiddel) as deel van die strategie om heidene te bereik. Op 'n sekondêre manier is hier dus aan die diens van genesing uitdrukking gegee. Bosch het hierteen indringende kritiek uitgespreek. Volgens hom word hierdie sogenaamde "hulpdienste" gedevalueer tot ' $n$ "hulpmiddel" en is dit nie genoeg besef nie dat ook die woordverkondiging volgens hierdie sisteem daarmee saam gedevalueer word. ${ }^{25}$ Buitendien lê ten grondslag van hierdie uitgangspunt ' $n$ dualistiese mensbeskouing en ' $n$ beperkte siening van wat heil is. Hierdie praktyk het in die laaste paar jaar in onbruik geraak onder andere vanweë die feit dat die staat die besit en bestuur van die sendinghospitale oorgeneem het.

e) Die diens van genesing het ' $n$ beperkte liturgiese karakter in die sin dat die name van siekes in die gemeente gewoonlik op die een of ander wyse, byvoorbeeld deur voorbidding tydens die kanselgebed, in die erediens ter sprake kom. Verder word daar heel waarskynlik in die prediking gewys op die feit dat gebede - ook die gebed vir siekes - verhoor word. Sodanige boodskappe pas in elk geval in by die verskillende besluite 
wat van tyd tot tyd deur kerklike vergaderings geneem is. So het die "Raad der Kerken" in Maart 1923 die sinodes geadviseer omtrent die besluite van die predikante-konferensie van 19 Januarie daardie jaar in Bloemfontein. Hiervolgens word verklaar dat liggaamlike genesing in antwoord op gelowige gebed 'n heerlike waarheid uit die Heilige Skrif is. Ter verduideliking is egter - eie aan die insigte van daardie tyd bygevoeg dat genesing as antwoord op die verhoring van gebede nie met die werking van die buitengewone gawe van gesondmaking verwar moet word nie. ${ }^{26}$

In die lig van bostaande omskrywing van die diens van genesing, moet die aard van die werk wat die kerk wel doen, positief waardeer word. Daaroor behoort daar geen twyfel te bestaan nie. Dit beteken egter nie dat die bogenoemde praktyk probleemloos of omvattend genoeg is nie. Die negatiewe fasette sal egter nie hier beredeneer word nie. Die beskrywing van die omvattender diens van genesing van ander kerke hieronder sal in elk geval krities inspeel op die bovermelde praktyk. Intussen sal net eers aandag gegee moet word aan die tradisionele afwysing van ' $n$ meer besondere faset van die diens van genesing, dit wil sê genesingsdienste binne die Ned. Geref. Kerk.

\subsection{Die afwysing van genesingsdienste}

Die vraag of die Ned. Geref. Kerk se diens van genesing nie verder verryk kan word nie, word veral dringend as daar na die groeiende teologiese arbeid en na die praktyke van ander erkende kerke gekyk word. Dan blyk dit gou dat daar fasette van die Ned. Geref. Kerk se diens van genesing is wat of nie ontwikkel nie, ò die moontlike ontwikkeling word teengestaan, ò enkele leemtes in die huidige praktyk word nie raakgesien nie, of dit word nie genoegsaam aan teologiese kritiek en - refleksie onderwerp nie. Daar is veral ook nie 'n beduidende groei in die liturgiese uitdrukking van hierdie diens nie. Die punt is dus: Waarom is genesingsdienste binne die Ned. Geref. Kerk tot nou toe onaanvaarbaar?

Sonder om op ' $n$ omvattende wyse hierop in te gaan kan net gesê word dat verskeie faktore ' $n$ rol gespeel het. Eerstens is die hou van genesingsdienste nie deel van die gereformeerde liturgiese erfenis nie. Tweedens het daar eeue verbygegaan waarin geglo is dat die charismata ná die tyd van die apostels nie meer voorgekom het nie. Dit het vervolgens aanleiding gegee tot 'n teologiese bedieningsmodel waarin die rol van die besondere ampte klem ontvang het - teenoor die charismata ${ }^{27}$ en waarin die pastor siekes gewoon net na die medikus verwys het. ${ }^{28}$ Die gereformeerde teologie het verder ' $n$ sterk rasionele karakter gehad. Dit verklaar in ' $n$ mate die sterk reaksie selfs ' $n$ oorreaksie(?) ${ }^{29}$ - teen die Pinksterbeweging. Die teologiese en praktiese gevare verbonde aan sommige van laasgenoemde groepe se genesingspraktyke is deurentyd uitgewys en teengestaan. ${ }^{30}$ Die kerk se ervaring ten opsigte van sommige persone binne hulle eie geledere wat hulle wel op hierdie bediening toegelè het - soos byvoorbeeld dr. Andrew Murray ${ }^{31}$ en later ds. C F Scheepers ${ }^{32}$ - was ook nie altyd besonder aangenaam nie. 


\section{Genesingsdienste in ander kerke: boustene vir 'n vernuwende praktyk}

Vervolgens word daar gekonsentreer op die teorie en die praktyk ten opsigte van genesingsdienste binne sommige van die kerke wat in die inleidende paragrawe genoem is. Die doel hiervan is om uit die ervaring van ander kerke te leer, om krities in te speel op die huidige praktyk van die Ned. Geref. Kerk en om die basis te lê vir die ontwikkeling van 'n model wat binne laasgenoemde kerk ontplooi kan word. Die volgende fasette kom na vore:

a) Ten opsigte van die verhouding tussen die diens van genesing en liturgie het die bogenoemde kerke meer aandag as die Ned. Geref. Kerk aan die saak gegee, meer voorstelle ontwikkel en meer liturgiese modelle geïmplementeer en ook 'n wyer ervaringsbasis ontwikkel. Dit word afgelei uit die beskikbare literatuur maar ook uit die feit dat daar in hierdie kerke eredienste of te wel genesingsdienste gehou word waartydens daar spesifiek en konkreet aan die nood van siekes - liggaamlik of geestelik lydendes - aandag gegee word. Dit beteken dat die erediens binne die raamwerk van 'n omvattende liturgie soms ò in die geheel òf gedeeltelik aan hierdie saak gewy word. Mense in nood word gewoonlik persoonlik en individueel bedien. Die viering van die Nagmaal vind soms by hierdie geleenthede plaas. Verskeie kerke is besig om liturgieë te ontwikkel wat vir hierdie geleenthede gepas is. ${ }^{33}$

Booth, ${ }^{34}$ wat optree as adviseur vir die "Health and Healing Ministries to the Methodist Churches' Division of Social Responsibility", sê byvoorbeeld hiervan dat net soos daar in die loop van die kerklike jaar sekere aspekte van die evangelie beklemtoon word inkarnasie - opstanding - die gawe van die Heilige Gees - is dit reg dat die "wholeness bringing" (genesende) krag van die evangelie beklemtoon moet word. Uit die aard van die saak sal daar in sekere gemeentes minder behoefte wees vir die viering hiervan in aparte genesingsdienste. Dit geld veral gemeentes waar daar ' $n$ volle aanvaarding is van die omvattende aard van die evangeliese boodskap en waar die relevansie daarvan ten opsigte van elke deel van ons wese - persoonlik, inter-persoonlik en sosiaal gesproke - beklemtoon word en waar daar dus gereelde geleenthede geskep word vir mense om handoplegging of moontlik salwing met olie te ontvang. Daarenteen voeg hy toe dat in gemeentes waarin daar by sommige lidmate onvoldoende simpatie en begrip is vir die genesingsbediening, liewer aparte genesingsdienste gehou moet word. Lidmate sal dus vooraf weet dat by hierdie spesifieke geleenthede daar 'n diens met die oog op genesing sal plaasvind en daar sal nie verleentheid ontstaan ten opsigte van diegene wat onvoorbereid na die (normale) diens gekom het nie.

Of sulke dienste binne 'n gereformeerde kerk as deel van die oggenderediens, die aanddiens, die Nagmaalsdiens of by 'n aparte geleentheid moet geskied, hang vanselfsprekend saam met die aard van die plaaslike situasie. Uit die aard van die saak sal dit dwaas wees om genesingsdienste op 'n onwillige gemeente af te forseer. Dit moet egter in gedagte gehou word dat hierdie dienste op sigself, dit wil sê ook in nie-verbale sin, ' $n$ betekenisvolle verkondiging van die evangelie kan wees. Veral die moontlikheid om genesingsdienste binne 'n gereformeerde kerk op 'n stil, rustige en ordelike wyse aan te bied, onderstreep hierdie stelling.

b) Atgesien van die eredienste bestaan daar ook talle ander formele en informele geleenthede binne die gemeentes waartydens daar op 'n toegespitse wyse aandag gegee word aan die dringende nood van die diegene wat genesing nodig het. Hiermee 
word tegelyk verwys na die funksionering van bepaalde diensaksies en gebedsgroepe wat spesifiek vir hierdie taak toegerus is. 35

Die optrede en funksionering van hierdie groepe is nie bedoel om kundige beraad uit te skakel of te devalueer nie. Trouens, hulle bediening volg dikwels ná beraad of hang ten minste op die nouste manier daarmee saam. ${ }^{36}$ Verskillende gemeentes het ook goed opgeleide groepe wat diegene vir wie daar in die openbare dienste gebid is en wat nog daarna sorg nodig het, bedien. Hulle kom dikwels in 'n groep van drie of vier met individuele lydendes, op ' $n$ weeklikse basis, vir beraad en intensiewe gebed, byeen. Hierdie nasorgperiode van ongeveer ' $n$ uur of twee per week kan oor sowat 'n maand strek alhoewel in ander gemeentes dit soms maande aanhou.

c) Genesing word nie net beperk tot een of ander faset van nood soos byvoorbeeld fisiese genesing nie. Genesing, of te wel die gebrek aan heelheid, word baie ruim geïnterpreteer. Mense met probleme van byvoorbeeld emosionele, geestelike, sosiale, seksuele en relasionele aard, word ook met gebed bedien.

Hierdie wye siening van genesing en die gepaardgaande bediening daarvan hang ten nouste saam met die teologiese arbeid wat deur verskeie persone en instansies gedoen word. Die begrippe "heelheid" of "wholeness" en "'n omvattende benadering", speel in hierdie opsig uiteraard 'n belangrike rol. ${ }^{37}$

Genesingsdienste kan en moet dus ingeklee word met die bediening aan die hele persoon in gedagte. Daar hoef dus nie net op die fisiese sy gekonsentreer te word nie. Verhoudinge het byvoorbeeld dikwels nood aan genesing en kan by hierdie geleenthede na die Here toe gebring word.

Die bogenoemde punte impliseer in elk geval een belangrike saak: Genesingsdienste kan 'n effektiewe onderdeel wees van 'n plaaslike gemeente se bediening aan sy eie mense sowel as aan diegene in die gemeenskap waarbinne dit gesetel is. Dit gee ook uitdrukking aan die "volle benadering" waarvoor Barnard pleit.

d) By byna elke genesingsdiens vind handoplegging plaas. Handoplegging het hier egter nie net die amptelike betekenis van "ordening" soos wanneer 'n proponent in ' $n$ gemeente bevestig word nie. Bo en behalwe die handoplegging deur die liturg word die handeling dikwels bloot gesien as "aanraking" van die wat saam bid. Binne gereformeerde kringe het KJ Kraan egter alreeds ten opsigte van die diens aan siekes, uitgebreide gedagtes oor handoplegging ontwikkel. ${ }^{39}$ In meer formele eredienste, soos byvoorbeeld in die Anglikaanse Kerk, wanneer die lydendes na vore kom en by die "altar rail" kniel om deur die priester met die Nagmaal bedien te word, volg ' $n$ meer formele, amptelike, handoplegging ná die bediening van die sakrament.

Vir lidmate van die Ned. Geref. Kerk is formele handoplegging in terme van genesing gewoonlik 'n vreemde begrip en 'n ongewone praktyk - alhoewel uitsprake van die Transvaalse Sinode in 1928 en 1948 dit alreeds as skriftuurlik bestempel het. ${ }^{40}$ Informele aanraking soos tydens ' $n$ gebed by ' $n$ siekbed vind egter dikwels plaas. Binne die sogenaamde liturgiese kerke is die meer formele aspek 'n algemene gebruik.

e) Salwing met olie word gewoonlik toegedien deurdat die vinger (of watte) in die (olyf-)olie gedruk word en die teken van die kruis daarna op die voorhoof van die persoon wat vir die bediening van genesing vra, gemaak word. Dit word algemeen aanvaar dat salwing net een keer tydens 'n bepaalde siektetoestand toegedien word. Handoplegging vind daarenteen meer kere plaas. ${ }^{41}$ Vanuit sy Anglikaanse agtergrond en sy persoonlike ondervinding sê biskop Maddocks: "The more I ponder on my case 
histories, the more am I led to believe that the sacrament of anointing can itself be fairly described as a healing explosion. ${ }^{42}$

Alles in ag genome beteken dit dat bogenoemde twee liturgiese handelinge met vrug as deel van die liturgiese verryking binne die Ned. Geref. Kerk benut kan word.

f) Feitlik oral waar die diens van genesing binne lokale gemeentes ontwikkel, is daar twee ander faktore wat ook na vore kom. Die eerste is dat ' $n$ spanbenadering gevolg word. Die tweede wat ten nouste hiermee saamhang, is dat dit nie net diegene in die kerklike ampte is wat betrek word nie. Diegene wat in ampte staan word dus op 'n kreatiewe wyse saam met die sogenaamde leke in hierdie dienswerk benut.

Hiermee word bedoel dat die ampte gewoonlik lidmate toerus vir hierdie dienswerk. Hierdie toerusting bestaan egter nie net uit teoretiese werk nie. "Gewone" lidmate word inderdaad mettertyd prakties betrek by die gebede en diens van genesing. Nuwe strukture van dienswerk kom dus op hierdie wyse tot stand. ${ }^{43}$ Sommige gemeentes se opleiding strek oor ' $n$ periode van ongeveer vier tot agt weke. ${ }^{44}$ Ander ampsdraers, soos byvoorbeeld die predikante van die genoemde gereformeerde gemeente in Oklahoma City, onderrig die hulpwerkers op 'n weeklikse basis vir ten minste nege maande alvorens hulle ingespan word. Daarna volg daar voortgaande opleiding binne die verskillende diensgroepe. ${ }^{45}$ Nog ander gemeentes, soos byvoorbeeld die First United Methodist Church in Tulsa, Oklahoma, gebruik nog 'n langer tydperk. Dit hang saam met hulle uiters suksesvolle program om ook "leke beraders" op te lei. ${ }^{46} \mathrm{~L}$ Thomas, wat deur sy kerk afgesonder word om groepwerkers vir die diens van genesing toe te rus, gebruik vir hierdie taak 'n intensiewe kursus wat oor 'n periode van twee jaar aangebied word. ${ }^{47}$

Gewone ervaring het geleer dat nie alle mense vir wie daar in kerklike genesingsdienste gebid word, op die spesifieke wyse wat hulle mag begeer, herstel nie. Daarom is die pastorale versorging noodsaaklik. Waar moontlik moet diegene wat met die oog op spesifieke node by hierdie geleenthede bedien word, dus vooraf en daarna pastorale aandag ontvang. Opgeleide diensgroepe is dus ' $n$ onontbeerlike faset in die gemeente se totale diens van genesing. Hierdie versorging sal egter nie die liturgiese handelinge oorbodig maak nie. Net so maak liturgiese handelinge ook nie ander aksies binne die gemeente oorbodig nie.

g) Feitlik vanselfsprekend is die kwessie van die genadegawe(s) van gesondmaking ook hiermee aan die orde gestel. Die beoefening en benutting van hierdie gawe met die oog op die opbou van die gemeente, word in hierdie kerke al hoe meer as vanselfsprekend aanvaar en ook van ampsweë aangemoedig. Ampsdraers en lidmate wie se bedieninge in hierdie opsig deur die plaaslike gemeentes erken word, word benut sonder dat daar ' $n$ ophef van hulle gemaak word. Dit blyk veral moontlik te wees binne die raamwerk van ' $n$ praktyk waarin ook ander charismata benut word en ander bedieninge binne die plaaslike gemeente ontplooi word. Genesing is dus gewoonlik nie die een uitstaande diens van die gemeente nie. Van diegene wat gevangenes besoek of betrokke is by die diens aan armes word net so veel (of net so min) kennis geneem as van diegene wat direk by die genesingsdienste betrokke is. Verder word probleme wat in die verband ondervind mag word grootliks uitgeskakel deurdat hierdie dienswerk hom uitstekend leen tot 'n groepskaktiwiteit wat onder die leiding van die ampte binne die kontoere van die plaaslike gemeente plaasvind. Wat die praktyk betref is dit verder byvoorbeeld uiters sinvol om 'n persoon wat gebruik word in die gawe van die woord van kennis, ${ }^{48}$ saam met iemand wat meerendeels in die gawe van genesing 
gebruik word en 'n ander persoon wat veral in die gawe van voorbidding diens lewer, in 'n groep te benut. Dit yerminder die misbruik wat uit een persoon se dienswerk mag voortvloei, nog verder. ${ }^{49}$

Ten opsigte van die genadegawes moet verder onthou word dat genesings wat plaasvind, of dit geleidelik of meteens gebeur, die nood van mense verlig en dat dit tot die verheerliking van die Naam van die Here lei. Aan die ander kant is die finale genesing steeds deur die graf heen en dit is tans ook deel van God se plan vir mense. h) Dit is verder nodig om daarop te let dat die kerke wat op die gebied van genesing ontwikkel, ook van kundiges soos byvoorbeeld professionele beraders en medici gebruik maak. Sommige van die gemeentes wat hierbo genoem is, het selfs kantore vir psigiaters, sielkundiges en maatskaplike werkers in hulle kerksentrums ingerig. 'n Unieke voorbeeld in hierdie verband is die benutting van die kerkkompleks van die St. Marlyborne kerk in Londen. Die gedeelte wat vroeër as grafkelder gebruik is, word vandag aangewend as ' $n$ sentrum waar daar kantore en ander fasiliteite vir die diens van genesing bestaan. Die Churches' Council For Health And Healing is hier gevestig maar ook die spreekkamers van leke en professionele beraders, pastore en medici. Verder is daar 'n kapèl en 'n sentrum vir musiekterapie. Die klem lê sterk op die omvattende benadering wat in die diens van genesing gevolg kan word. ${ }^{50}$ Dit alles dra daartoe by dat die ongesonde spanning wat daar in sommige kringe tussen die mediese wetenskap en die kerklike diens van genesing bestaan op ' $n$ heilsame wyse in hierdie kerke deurbreek word.

Waar nodig word lidmate dus na persone in die professionele hulpprofessies verwys. Die omgekeerde is ook waar: lidmate word op die regte tyd deur hierdie beraders weer na die pastor of diensgroep terugverwys - onder andere met die oog op die deelname aan die volgende gemeentelike genesingsdiens. Dit is in die verband interessant om daarop te let dat professionele beraders wat in die VSA aan die Association for Christian Therapists behoort, daarvan getuig dat hulle self ook dikwels tydens of ná berading hulle pasiënte/kliënte met handoplegging en gebed bedien. Trouens hulle getuig ook dat hulle soms die diens van bevryding (van bose magte) toepas om die wat in nood is, effektief te kan help. ${ }^{51}$

'n Ander variasie is natuurlik ook moontlik: die benutting van hierdie kundiges in die bogenoemde gebedsgroepe. Wise sê in die verband dat hulle gevind het dat die professionele mense se opvoedkundige agtergrond dikwels daartoe bydra dat hulle verbeterde waarnemingsvermoë op 'n sinvolle wyse in hulle gebede neerslag vind. Sommige van hulle bid makliker vir emosionele steurnisse terwyl ander meer ingestel is op fisieke nood. ${ }^{52}$

i) Die genesingsdienste waarop hierbo gesinspeel is, het gewoonlik 'n baie sterk gemeentelike karakter. Hiermee word bedoel dat die diens binne die raamwerk van die plaaslike gemeente gehou word. Maar dit beteken onder andere ook dat gemeentes ' $n$ sterk bewussyn van hulle een-liggaam-wees ontwikkel. Die nood van lydendes word dus al hoe meer gesien en ervaar as eie nood. Meer nog: gemeentes besef ook al hoe meer dat hulle eintlik as "healing communities" behoort te funksioneer. Faktore wat as siekteverwekkend beskou kan word en wat binne die plaaslike gemeente bestaan, word dus makliker geïdentifiseer en ook uit die weg geruim. Hiermee saam word die belangrikheid van gesonde, ondersteunende, diensbare, liefdevolle verhoudinge en koinonia binne die plaaslike gemeente, op die voorgrond geplaas. ${ }^{53}$ Die liturgiese viering van genesing en heelheid het dus 'n genesende en helende uitwerking op die 
gemeente. Andersom gesê: Genesingsdienste kan die korporatiewe en individuele geestelike ingesteldheid binne die gemeente op 'n positiewe wyse bevorder. Die spesifieke aard van hierdie dienste lei dikwels tot 'n diepgaande resultaat wat mense op 'n omvattende wyse beïnvloed. Daar is buitendien 'n besondere waarde in korporatiewe handelinge binne die gemeente. Verreikende dinge kan gebeur wanneer mense in liefde verenig om in die Naam van die Here op te tree.

j) Die ontwikkeling van 'n eiesoortige genesingsbediening en 'n gepaardgaande teologie was vir die Anglikaanse kerk noodsaaklik in die lig van die geweldige invloed wat die Christian Science beweging onder die kerk se lidmate begin kry het. ${ }^{54} \mathrm{Vir}$ die Ned. Geref. Kerk kan die ontwikkeling van hierdie bediening 'n positiewe stap vorentoe wees in die daarstelling van ' $n$ alternatief teenoor ' $n$ bedieningspatroon van sommige rondreisende "healing evangelists" of van ander kerke of groepe waarteen gedurig gewaarsku moet word. Uit die aard van die saak is dit maklik en ook legitiem om ander modelle van genesing en genesingsdienste krities onder die loep te neem. In hierdie opsig kan daar met reg kapsie gemaak word teen bepaalde praktyke van sogenaamde rondreisende "healing evangelists" en groot geldelike bedrae wat telkens ter sprake kom. Ook die ander assosiasies hieraan verbonde soos tentdienste en luidsprekers, plakkate en die aansprake op mirakel-genesings wat sal plaasvind, 'n ongebalanseerde klem op fisiese genesing en "bewyse" wat dit oor God of die vermoë van die bidder(!) sou lewer, vra inderdaad ernstige beoordeling. Dit kan selfs beweer word dat die aversie teen bepaalde modelle van genesing daartoe lei dat ander groepe en persone nie in hierdie diens betrokke raak nie. ${ }^{55} \mathrm{Om}$ egter 'n patroon daar te stel wat ontdaan is van al hierdie negatiewe fasette en waarna die gemeenskap met respek kan opkyk, is nie so maklik nie. En tog behoort 'n kerk wat aan die helende krag van sy Hoof uitdrukking wil gee, hierdie taak te kan aanpak.

k) In gemeentes of ringe waar die diens van genesing sinvol ontplooi, kan die benutting van sogenaamde genesingshuise oorweeg word. Dit sal sommige persone wat oor 'n langer termyn gesond word, in staat stel om op 'n gereelde basis (moontlik daagliks) van verskillende persone in die gemeente intensiewe voorbidding, amptelike aandag en handoplegging, versorging en begeleiding te ontvang. ${ }^{56}$

I) Soms word bo en behalwe die diens in die plaaslike gemeente ook ekumeniese genesingsdienste gehou. Die deel van gemeenskaplike belange in die kerk se diens van genesing het dikwels al gemeentes van verskillende kerke nader aan mekaar gebring. Wanneer dit gebeur vind genesing gewoonlik op meer as een manier plaas. ${ }^{57}$ Binne die verskeurde kerklike verhoudinge in ons land kan hierdie faset mettertyd ' $n$ dinamiese krag word.

\section{Enkele moontlike gevare}

Dit is vanselfsprekend dat die invoering van 'n nuwe liturgiese praktyk groeipyne kan veroorsaak. Om die waarheid te sê, selfs die hantering van bestaande liturgiese fasette van die erediens soos prediking en die viering van die Nagmaal, hou Sondag vir Sondag ook bepaalde gevare in. Ten spyte hiervan is die kerk egter gehoorsaam in die deurvoering daarvan. Die vraag is dus of die tyd nie ryp is om ook die helende krag van God - en trouens die opdrag: genees die siekes - op 'n liturgiese wyse tot uitdrukking te bring nie. 
Weer eens kan dit beklemtoon word dat elkeen van die boustene in die paragrawe hierbo genoem, aanleiding kan gee tot probleme wat ondervind kan word. Aan die ander kant moet dit dan ook met erns gesê word dat juis hierdie sake met goeie gevolg in die genoemde erkende kerke toegepas word.

Een gevaar wat uitgesonder kan word en wat eintlik die meeste ander probleme omvat, is dat ' $n$ gemeente onvoorbereid in hierdie diens betrek kan word. In hierdie opsig moet die wyse raad en voorbeeld van dr. Wise (Gereformeerde kerk, Oklahoma City) as goudwerd beskou word. Hy het bevind dat dit nuttig was om sowat ses maande tot 'n jaar vooraf met belangstellendes ('n aantal ouderlinge) 'n studie- en gebedsgroep te begin, dit wil sê voordat hierdie faset van die bediening van genesing in alle erns in die gemeente as geheel geïmplimenteer is ${ }^{.58}$ Voorbereiding het natuurlik ook die sogenaamde gebeds- of diensgroepe (Servants in prayer) en die gemeente self ingesluit. $\mathrm{Na}$ die suksesvolle infasering van hierdie dienswerk in hulle gemeente vra-sê Wise: "Why had this ministry developed and flourished without controversy or confusion? The answer is basic: a carefully-laid Biblical foundation and theological outlook had changed old attitudes of resistance and opened doors to new inquiry. ${ }^{.59}$ Die punt is dus dat goeie voorbereiding die saak op 'n gesonde fondament kán vestig en dat probleemsituasies oorkom kan word.

\section{Riglyne vir die implementering van 'n genesingsdiens}

Soos blyk uit die gegewens hierbo is die probleem ten opsigte van genesingsdienste in die Ned. Geref. Kerk die feit dat daar nòg 'n teologiese teorie nòg 'n praktyk is om as ' $n$ basis vir die ontwikkeling van so ' $n$ bediening te benut. Soos uit die voorafgaande gegewens geblyk het, is dit egter wel moontlik om hierdie liturgiese handelinge binne die raamwerk van die gereformeerde liturgie in te pas en ook om dit te verryk. Tot dusver is daar in die beredenering gepoog om 'n teoretiese raamwerk daar te stel waarbinne so 'n praktyk wel kan ontwikkel. Dit sal nie hier punt vir punt herhaal kan word nie. In die algemeen gesproke moet egter gesê word dat hierdie geïmpliseerde raamwerk put uit 'n bedieningsmodel wat elders as "congregational healing" 60 of as 'n "integrated model of healing" 31 bekend staan.

Wat die implementering van hierdie model betref is dit absoluut vanselfsprekend dat daar eerstens deeglike voorbereiding moet wees. In hierdie fase kan daar van die literatuur wat hierbo aangehaal is, met groot nut gebruik gemaak word. ${ }^{62}$ Voorbereiding sluit natuurlik die opleiding van dienswerkers in. Net so belangrik is die ingesteldheid van die gemeente - en die siekes - wat deur onderrig en prediking hiervoor ryp moet word. Uit die aard van die saak is onderwerpe soos die verhouding tussen die mediese wetenskap en genesing op gebed, gebed en gebedsverhoring, gawes van die Gees en so meer hierin belangrik.

In die tweede plek, moet die model ook toegepas word. Ten opsigte van hierdie fase word voorgestel dat 'n Sondagaanddiens met sy buigsamer karakter (aanvanklik) hiervoor benut word. ${ }^{63} \mathrm{Na}$ die prediking kan gemeentelede wat spesifieke gebed nodig het, uitgenooi word om na vore te kom. Afhangende van die plaaslike situasie kan twee of drie stoele vooraf in die liturgiese ruimte geplaas word. Die liturg, toegeruste ouderlinge en ander lidmate kan in 'n groep van drie of vier rondom so 'n persoon staan en sy/haar nood voor die Here lê. Sonder om die saak van handoplegging op die spits 
te dryf, kan hierdie persone heel eenvoudig die persoon wat sit op die skouer of op die hoof aanraak. Indien die saak in die gemeente goed voorberei is, kan salwing met olie ook (mettertyd) as ' $n$ liturgiese daad benut word

Aangesien meer as een persoon tegelyk bedien kan word en vanweë die persoonlike aard van die probleme kan dit goed wees as die onderskeie groepe se gebede net in hulle eie kring hoorbaar sal wees. Die belangrikheid van gemeentelike deelname binne die gereformeerde erediens kan op ' $n$ intense wyse geaktualiseer word deurdat die gemeente meedoen aan die voorbidding deur stilgebed of deur die sing van psalms en gesange wat spesifiek na die genesende werk van God verwys. In die verband kan net terloops gevra word of die liedereskat van die gereformeerde kerke nie ' $n$ aanduiding is van hoe min daar in die verlede op die diens van genesing gekonsentreer is nie. Onder die huidige gesange is daar net in minder as 20 strofes verwysing na die begrippe wat hiermee in verband staan: genees, geneesheer, genesing, gesond, heling. ${ }^{64}$ Sommige van hierdie gesange verskuif boonop die klem van liggaamlike genesing na ander fasette soos die genesing van eiesinnigheid (16:4), nyd (37:3), en die wonde van ons sondaarsharte (226:3).

Orrelspel - soos tydens die opneem van die offergawes - kan ook benut word tydens die gebedsbediening.

Om die bediening te laat vloei kan die gebruik van ander kerke gevolg word waarvolgens mense in nood vóóraf hulle spesifieke probleem op 'n kaartjie wat verskaf word, neerskryf. ${ }^{65}$ Dit sal diegene wat in die diens van genesing betrokke is in staat stel om onmiddellik tot gebed oor te gaan. Hulle hoef dan nie in 'n mini-beradingsituasie betrokke te raak nie. In ander kerke is dit egter nie ' $n$ probleem nie omdat die gebedsgroep bewus is van die omstandighede aangesien hulle van te vore met die behoeftige kennis gemaak het. Hulle het die persoon in nood - moontlik iemand wat 'n groot operasie tegemoet gaan - dus heel waarskynlik aanbeveel om in die midde van die gemeente die diens van genesing liturgies mee te maak. In so 'n geval kan dit natuurlik ook gebeur dat ' $n$ medikus of ' $n$ professionele berader die behoeftige vergesel. Afhangende van die situasie kan daar egter ook direk van die behoeftige verneem word waarvoor daar gebid moet word.

As die gebed vir ' $n$ bepaalde behoeftige afgehandel is, kan ' $n$ volgende persoon genooi word om die sitplek in te neem. Uit die ervaring van ander kerke blyk dit dat as daar meer as een stoel en meer as een groep is die vrymoedigheid van lidmate groei om nader te kom - al die aandag sal nie net op een persoon wees nie. Hierdie is uit die aard van die saak geen vaste beginsel nie en dit hang van elke plaaslike situasie af. Ná die diens bly die belangrike faset van nasorg nog oor. Dit begin by die liturg en of pastor maar weer eens moet gesê word dat die bestaan van 'n diensgroep wat hiervoor verantwoordelikheid aanvaar, noodsaaklik is. ${ }^{66}$

Die derde fase in die ontplooiing van hierdie diens is net so belangrik. Die evaluering en ontwikkeling van ' $n$ verbeterde teorie en praxis moet ten alle tye nagestreef word. Dit kan deur die kerkraad in samewerking met sowel die diensgroep as met diegene vir wie daar gebid is, gedoen word. 


\section{6. 'n Slotwoord}

Die implementering van bogenoemde voorstelle sal op vele fasette van die gemeente 'n invloed uitoefen. Dit is byvoorbeeld vanselfsprekend dat dit die sistematies-teologiese denke oor hierdie aangeleentheid sal raak. Dit moet verwelkom word. Trouens die ontwikkeling van ' $n$ grondige teologie oor genesing is iets wat dringend en noodsaaklik is. ${ }^{\text {"7 }}$ Hierdie verdere nadenke sal vervolgens lei tot ' $n$ meer diepgaande neerslag in die liturgie. Hierdie wisselwerking sal net kan bydra tot ' $n$ sinvoller implementering van die kerklike diens van genesing. Maar nog meer fasette kan genoem word: Dit kan daartoe lei dat ' $n$ liturgiese vorm geskep word wat beter aanpas by die mens van die hede, dat die Ned. Geref. Kerk nouer aansluit by die res van die Christendom $^{68}$, dat die evangelie op 'n meer effektiewe wyse gekommunikeer word ${ }^{69}$, dat lidmate en die charismata wat deur hulle werk sonder konflik benut kan word ${ }^{70}$, dat gemeentes as genesende gemeensskappe kan ontwikkel ${ }^{71}$, dat daar meer klem gelè word op die bediening van die gemeente as liggaam en dat persone in nood op ' $n$ meer omvattende wyse bedien word ${ }^{72}$. Trouens, dit kan op 'n effektiewe wyse uitdrukking gee dat die kerk gehoorsaam is aan een van die duidelikste bevele, naamlik om die evangelie te verkondig en om die siekes gesond te maak $^{73}$.

In die algemeen gesproke kan dit verder beweer word dat die voorstelle kan Inpas by die riglyne wat in die onlangse verlede deur teoloë getrek is ten opsigte van liturgiese vernuwing - veral in soverre dit vryheid en kreatiwiteit betref. ${ }^{74}$ Uit die vooraf́gaande blyk dit ook dat die vraag wat vroeër gevra is positief beantwoord kan word. Die voorgestelde liturgiese model ten opsigte van die diens van genesing kan inderdaad binne die hoofraamwerk van die gereformeerde liturgiese beginsels inpas en dit kan veral 'n onderafdeling van die liturgie self, soos byvoorbeeld die diens van voorbidding, op ' $n$ baie aktuele wyse verryk. Uit die aard van die saak beteken dit nie dat voorbidding elke Sondag net op hierdie wyse gestalte moet kry nie.

In die laaste instansie sal dit ook beteken dat die nood van mense verlig word en dat die Naam van die Een wat in die erediens aanbid word, verheerlik word.

\section{NOTAS}

Vgl. M Maddocks, The Christian healing ministry, London ${ }^{6} 1984,97-112$.

Vgl. bv. D Duncan, Health and healing: a ministry to wholeness, Edinburgh 1988, 18, vir 'n beskrywing van die werk van biskop M Maddocks.

Vgl. bv. hiervoor die werk van The Methodist Church, The United Reformed Church, The Churches' Council For Health And Healing. The Institute For Religion And Medicine, en nog meer in $\mathrm{H}$ Booth, Healing is wholeness: a resource book to encourage healing ministry initiatives in the local church, London, 1987, x,1,139-145. Die werk van die gereformeerde predikant dr. KJ Kraan Opdat u genezing ontvangt: Handboek voor de dienst der genezing, Hoornaar 1973 en sy drie volumes Genezing en bevrijding, Kampen 1983, 1984, 1986, getuig van vele ontwikkelinge op hierdie gebied. Minneapolis 1987, 278-286. 
5 Vgl. JK Wagner, Blessed to be a blessing, Nashville ${ }^{3} 1986$.

Vgl. R Bayley, The healing ministry of the local church, Oklahoma City 1983, 9-12.

Vgl. V Synan, "The wisdom of Dr Robert Wise", Charisma and Christian life vol 13 (no 11) (1988). 60 .

8 Psychology, medicine and Christian healing, San Francisco 1988, 194-199.

9

Genezing en bevrijding: Deel 11, Spanningen in de dienst der genezing, Kampen 1984, 141-147.

10 Healing, Toronto/New York ${ }^{7} 1980,3 ; 251-261$.

$11 \mathrm{Vgl}$. E O'Sullivan, "The pastoral care of the sick: the challenge of liturgical changen, Doctrine and life vol 38 (1988), 364-371.

12 Vgl. E Milingo, The world in between: christian healing and the struggle for spiritual power, London 1984? 11-30. Kraan, Opdat ..., 20, noem Jakobus 5 die Magna Charta van die diens van genesing in die Nuwe Testament.

13 A.w., 1.

14 Persoonlike gesprek, 25 September 1988 te School of World Missions, Fuller Theological Seminary, Pasadena, California. Vgl. ook Wagner se publikasie How to have a healing ministry: without making your church sick, Ventura, California 1988, wat saamhang met hierdie oortuiging. Vgl. ook die talle voorbeelde van ontwikkelinge van bedieninge in verskillende wêrelddele waarna hy verwys.

15 A.w., 5.

16 JJ Müller, "Geloofsgenesing", Ongepubliseerde referaat gelewer tydens die predikante-konferensie (Suid-Transvaal) te Buffelspoort, 10-11 Maart 1975, 5.6, het alreeds die hou van sogenaamde "sieke dae" of "genesingsbyeenkomste" bepleit.

17 Algemene Kommissie Leer en Aktuele Sake, Riglyne ten opsigte van die Charismatiese beweging en die charismatiese gawes, Pretoria 1979.

18 Vgl. JG van der Watt, "Die Heilige Gees en die toerusting vir die bediening in Nuwe-Testamentiese perspektief" in Die bediening in die kragveld van die Heilige Gees (JG van der Watt, AC Barnard \& AJ Smuts) Pretoria 1989, 14.

19 AC Barnard, "Die erediens in die kragveld van die Heilige Gees" in Die bediening in die kragveld van die Heilige Geos (JG van der Watt, AC Barnard \& AJ Smuts) Pretoria 1989, 32.

20 Aangehaal deur J Richards, But deliver us from evil: an introduction to the demonic dimension in pastoral care. London 1974, 6.

21 Vgl. belangrikeste fasette hiervan soos aangetoon deur AC Barnard, Die erediens, Pretoria $1981,384-480$. 
Vgl. WJ Hollenweger, "Healing through prayer: superstition or forgotten christian tradition?", Theology vol 92 (1989), 166-174.

Vgl. Booth, a.w., 2-3.

Vgl. LLJ Visser, Die charismata, Pretoria 1978, 77.

Vgl. DJ Bosch, "Sending deur woord en daad" in Sending in meervoud - Kerk en wêreld: Teologiese studies oor sending van die kerk in die wêreld nr.5, Pretoria 1968, 19-27.

Handelingen van de Achste Vergadering van de Raad der Ned. Ger. Kerken in Zuid-Afrika - gehouden te Parijs, O.V.S. 8 Maart 1923 en volgende dagen. Kaapstad, 21-23

Van der Watt, a.W., 14

Vgl. HI Lederle, "Models of healing: a denominational charismatic perspective" in Healing in the Name of God (Edited by PGR de Villiers), Pretoria 1986, 123-126, wat die gereformeerde siening onder sy "Tradisionele model" en meer spesifiek die "Dispensasionalisme" groepeer.

Vgl. Kraan, Opdat u genezing ontvangt: Handboek voor de dienst der genezing, Hoornaar, 1973, 485, wat sê/vra of die besluite van die Transvaalse Sinode van die Ned. Geref. Kerk (1957) nie dui op 'n "anti-Pinksterkramp" nie.

Kraan, a.w., 223-226; J P Theron, Gebed en genesing in die pastorale sorg, Ongepubliseerde D.D. proefskrif, Universiteit van Pretoria, Pretoria 1969, 145-155,.

Vgl. Theron, a.w., 159-174.

Vgl. IL Ferreira, Die charismata en die Nederduitse Gereformeerde Kerk, Pretoria 1975, 12.

Vgl. R Bayley, a.w., 30, vir 'n voorbeeld uit gereformeerde kringe. 'n Metodis in die VSA, JK Wagner, a.w., 99.122, gee nege sulke voorbeelde. Enkele eksperimentele voorbeelde uit Engeland word verskaf deur Booth a.w., 101-125.

A.w., 3.

So word sommige Sondagaandbyeenkomste in die gereformeerde gemeente Our Lord's Community Church (Oklahoma City), "Fellowship of the Healing Christ" genoem. Die helpers staan bekend as "Servants in prayer". Vgl. RL Wise, "Healing ministry includes the laity" Renewal News (July-August) 1987, 5.

Vgl. die titel van die kursus aangebied deur die First United Methodist Church van Tulsa (Oklahoma, VSA): LD Thomas, The ministy of counseling prayer, Oklahoma 1989.

Vgl. bv. KL Bakken, The call to wholeness: health as a spiritual journey. New York 1987; Duncan a.w., 48-55.

A.w., 29.

Vgl. vir die terapeutiese waarde van handoplegging Booth, a.w., p.12. Vgl. Kraan, Opdat ..., 38-56.

Handelingen, N.H. of G. Kerk van S.A., Pretoria 1948, $23,471$. 
Vgl Booth a.w., 13-14; Maddocks, a.w., 116-120.

A.w., 121.

Vgl. behoefte genoem deur Van der Watt, a.w., 14.

Bv. Vineyard Christian Feliowship, Anaheim, California. Sien ook die uiteensetting van dit wat aan kursusgangers voorgehou word in J Wimber \& K Springer, Power healing, London 1986.

Vgl. Wise, Renewal news, (November-December 1987), 5-6.

Persoonlike gesprek met predikante van die gemeente, Tulsa Oklahoma, 27 September 1988.

L Thomas, The healing team, New York 1987, 178-179.

48 Vir ' $n$ beskrywing en ' $n$ beoordeling van die werking van hierdie gawe soos dit in charismatiese kringe verstaan word sien DC Lewis, (Appendix D) Signs and wonders in Sheffield: a social anthropologist's analysis of words of knowledge, manifestations of the spirit, and the effectiveness of divine healing, in J Wimber \& K Springer, a.w., 252-273. Vgl. ook sy uitvoerige ondersoek: DC Lewis, Healing: fiction, fantasy or fact?, London 1989, 129-161.

49 Vgl. ook $A B$ du Toit, "Die charismata - 'n Voortsetting van die gesprek: Pauliniese kriteria ten opsigte van die beoefening van die individuele charismata volgens 1 Kor 12-14" NGTT vol $201979,189-200$, wat alreeds duidelike riglyne vir die beoefening van die charismata aangetoon het.

Vgl. CH Cooke, Health is for God, London 1986, 93-98. Vgl. ook Kelsey, a.w., 317.

Vgl. M Linn, "Introduction." in Deliverance prayer (Edited by D \& M Linn), New York 1981, 7.

Persoonlike gesprek, Oklahoma City, Oklahoma VSA, 4 Oktober 1988.

53 Vgl. JPL Jonker, "Koinoterapie: Vernuwing in genesing." in Dit is Ek, die Here, wat julle gesond maak (Onder redaksie van HI Lederle \& JPJ Theron), Pretoria 1985, 132-140; Maddocks, a.w., 72,86. Booth, a.w., 10-11; Soos uit die titel blyk laat $U$ Bach, "Heilende Gemeinde"?: Versuch, einen Trend zu korrigieren. Neukirchen-Vluyn 1988, egter kritiese klanke hoor ten opsigte van sekere begrippe wat volgens hom te maklik in hierdie verband gebruik word.

54 KJ Kraan, Genezing en bevrijding 2: Spanningen in de dienst der genezing, Kampen 1984 , 123.

Vgl. Wimber, a.w., 39-41.

$56 \mathrm{Vgl}$. Booth, a.w., 143, se lys van sulke "Residential homes of healing" in Engeland en J Glennon, How can I find healing?, London 1984, 67-69, se beskrywing van die invloed van sulke tehuise.

Booth, a.w., 3. 
Vgl. R Wise, "Reshaping attitudes about healing." Renewal news, (Nov-Dec) 1987, 5; Booth, a.w., 4.

Persoonlike gesprek, Oklahoma City, Oklahoma VSA, 4 Oktober 1988.

Lederle, a.w., 134-139.

J Wimber \& K Springer, a.w., 181-207.

Hierby kan ook die volgende gevoeg word: Division of social responsibility of the Methodist Church, In search of health and wholeness, London 1985; United Reformed Church, Health and healing: a study kit, London 1985; WJ Bittner, Heilung: Zeichen der Herrschaft Gottes, Neukirchen-Vluyn 21988, 114-123, bied deur sy "Seelsorgerliche Einzelfragen" materiaal wat in die prediking aangesny kan word.

63 Ook Bittner, a.w., 110-114, noem die aanddiens as een van die geleenthede wat sinvol hiervoor benut kan word. Sy gedagte is dat daar so min as moontlik versteuring van die bestaande eredienspatrone moet plaasvind. Dit is wel moontlik aangesien die diens van genesing volgens hom eintlik binne die bestaan van die gemeente niks nuuts en ook niks besonders is nie.

64 Vgl. die konkordansie-inskrywings in WJB Serfontein \& GM Kettley, Konkordansie van die Evangeliese Gesange, Kaapstad 1979.

65 Vgl. bv. Bayley, a.w., 31 en die praktyk van The National Presbyterian Church, Washington D.C.

66 Vgl. JPJ Theron, "Vind daar nog genesings en bevrydings plaas?: Enkele perspektiewe op grond van ' $n$ empiriese opname." in Dit is EK, die Here, wat julle gesond maak (Onder redaksie van HI Lederle en JPJ Theron), Pretoria 1985, 209-210, vir die belangrikheid van gesonde ondersteuning en die moontlikheid wat dit bied tot die behoud van genesings wat op hierdie wyse gerealiseer het.

67 D Duncan, a.w., 134.

68 Vgl. die beginsels van liturgiese vernuwing genoem deur AC Barnard, Die erediens, Pretoria 1981, 494-495.

69 Vgl. WJ Hollenweger, Theology 166-174; J Wimber \& K Springer, Power evangelism: signs and wonders today, London $1986,66-67$.

70 JK Wagner, a.w., 94.

71 Duncan, a.w., 62-73.

72 Vgl. JPL Jonker, "New accents on the healing ministry of the church" in Healing in the Name of God (Edited by PGR de Villiers), Pretoria 1986, 143-151.

73 Duncan, a.w., 63-64. 
74 Vgl. AC Barnard, "Vernuwing van die erediens" in Praktiese Teologie in Suid-Afrika 6: Vernuwing van die erediens (Onder redaksie van AJ Smuts), Pretoria 1988, 55-56; JC Muller, "Vastheid, variasie en kreatiwiteit in die liturgie" in Praktiese Teologie in Suid-Afrika 3: Perspektiewe op die erediens (Onder redaksie van AJ Smuts), Pretoria 1987, 39. 